\title{
Physicochemical characteristics of organic honey samples of africanized honeybees from Parana River islands
}

\author{
Características físico-químicas de mel orgânico de abelhas africanizadas produzido nas ilhas do Rio Paraná \\ Eloi Machado ALVES ${ }^{1}$, Maria Josiane SEREIA², Vagner de Alencar Arnaut de TOLEDO ${ }^{3 \star}$, Luis Carlos MARCHINI ${ }^{4}$, \\ Carolina Antunes NEVES ${ }^{3}$, Tiago Cleyton Simões de Oliveira Arnaut de TOLEDO 3 , \\ Daniela de ALMEIDA-ANACLETO ${ }^{5}$
}

\begin{abstract}
This research was carried out to evaluate the physicochemical composition of organic honey in Paraná River islands, in Porto Brasílio, State of Paraná. Honey was harvested directly from super of the colonies in three apiaries spread in the Floresta and Laranjeira Islands, from August 2005 to August 2006. Twenty-four samples of organic honey produced by Africanized honeybees were evaluated. The following parameters were analyzed: $\mathrm{pH}$, acidity, formol index, hydroxymethylfurfural, ashes, color, electric conductivity and moisture. Three replications per sample were performed for laboratorial analysis, giving the means and standard deviation. Most honey samples were in conformity with the Normative Instruction 11 from October 20, 2000. However, 4.17\% were not in accordance with the moisture standards, $8.33 \%$ showed high concentrations of hydroxymethylfurfural, thus, totalizing $12.50 \%$ of non-complying samples. Nevertheless, $87.50 \%$ of the analyzed honey samples are within the standards, being characterized as an organic product of excellent quality, with good commercialization perspectives in the market.
\end{abstract}

Keywords: Apis mellifera; honey composition; physico-chemical analysis.

\section{Resumo}

O presente trabalho teve como objetivo avaliar a composição físico-química de mel orgânico produzido nas ilhas do rio Paraná, na região de Porto Brasílio, Estado do Paraná. O mel foi coletado diretamente das melgueiras das colônias avaliadas, em três apiários distribuídos em pontos estratégicos nas ilhas Floresta e Laranjeira de agosto de 2005 a agosto de 2006. Vinte e quatro amostras de méis orgânicos produzidos por abelhas Apis mellifera africanizadas foram avaliadas. Os parâmetros analisados foram: $\mathrm{pH}$, acidez, índice de formol, hidroximetilfurfural, cinzas, cor, condutividade elétrica e umidade. Para as análises laboratoriais foram realizadas três repetições por amostra, obtendo-se a média e o desvio padrão. A maioria das amostras de méis avaliadas apresentou-se em conformidade com o determinado pela Instrução Normativa 11, de 20 de Outubro de 2000. Entretanto, 4,17\% apresentaram-se fora dos padrões pela questão da umidade e 8,33\% devido às altas concentrações de hidroximetilfurfural, totalizando $12,50 \%$ de amostras fora do estabelecido pela norma vigente. Contudo, pode-se concluir que $87,50 \%$ do mel analisado está de acordo com a normativa vigente, sendo um produto orgânico de excelente qualidade, com expectativa de boa aceitação no mercado.

Palavras-chave: Apis mellifera; composição do mel; análises físico-químicas.

\section{Introduction}

The environmental preservation area in the Parana River islands has a great potential for producing organic honey. This product has different characteristics and is appreciated in the international market, since it is contaminant-free. Therefore, the characterization of this honey is important for its identification, standardization and marketing.

The honey composition depends, basically, on the nectar composition of each vegetal species, which gives its specific properties, while both climate and beekeeper handling have less influence (WHITE JUNIOR, 1978). However, the chemical composition of honey and some physical parameters are found within a certain range, allowing its quality control (PEREIRA, 1983).

Honey production depends on the abundance and quality of flowers in the worker honeybee action area. Thus, since the Brazilian flora is very diverse, due to its territorial extension and the existing climate variability, it is essential to characterize the regional honey and set standards, taking into consideration the vast botanical diversity and climate variations of each region (MARCHINI; SODRÉ; MORETI, 2004a).

\section{Received 28/7/2009}

Accepted 18/5/2010 (004343)

${ }^{1}$ Centro de Ciências Agrárias, Biológicas e Ambientais, Universidade Federal do Recôncavo da Bahia - UFRB, Rua Rui Barbosa, 710, CEP 44380-000, Cruz das Almas, BA, Brasil

2 Coordenação de Tecnologia e Engenharia de Alimentos, Universidade Tecnológica Federal do Paraná - UTFPR, Campus Campo Mourão, BR 369, Km 0,5, CP 271,

CEP 87301-006, Campo Mourão, PR, Brasil

${ }_{3}^{3}$ Departamento de Zootecnia, Universidade Estadual de Maringá - UEM, Av. Colombo, 5790, Bloco J-45, CEP 87020-900, Maringá, PR, Brasil, e-mail: abelha.vagner@gmail.com

${ }^{4}$ Departamento de Entomologia e Acarologia, Escola Superior de Agricultura "Luiz de Queiroz", Universidade de São Paulo - USP, Av. Pádua Dias, 11, CEP 13418-900,

Piracicaba, SP, Brasil

${ }_{5}^{5}$ Instituto Federal Baiano, Campus Santa Inês, Km 2,5, BR 420, Zona Rural, CEP 45320-000, Ubaira, BA, Brasil

*Corresponding author 
The organic honey certification has different characteristics, since it is a pesticide-free product and well appreciated in the international market. The basic requirement is the ability to control the product origin and the production routine (BUAININ; BATALHA, 2007).

This research was carried out to characterize organic honey of Apis mellifera Africanized honeybees produced in Paraná River islands, comparing the results to those set by the Brazilian legislation.

\section{Materials and methods}

Honey samples produced in three apiaries were harvested, two from Floresta Island (apiary A - S 22 ${ }^{\circ}$ 51' 27.3"; W $53^{\circ} 29^{\prime} 35.6^{\prime \prime}$ and apiary B - S $22^{\circ} 54^{\prime} 24.2^{\prime \prime}$; W $53^{\circ} 33^{\prime} 51.9^{\prime \prime}$ ) and an apiary in Laranjeira island (apiary C - S 22 $2^{\circ} 53^{\prime} 59.0^{\prime \prime}$; W 533ㅜ $\left.33^{\prime} 51.9^{\prime \prime}\right)$, it Figure 1.

The region climate is temperate humid with hot summer "Cfa" by Köppen classification (MAAK, 1968). Rainfall is distributed throughout the year, with the highest volume from September to December and the lowest from June to August, always higher than $30 \mathrm{~mm} /$ month (INSTITUTO..., 1994).

Twenty-four honey samples were analyzed, with 22 collected directly from the colonies, within the monthly honey storage in the selected beehives, whenever possible. Two samples were harvested by the beekeepers in their apiaries. Samples were collected from August 2005 to August 2006. However, the harvesting of the honey stored in honeycombs took place from November 2005 to February 2006. There was not honey stored in another months.

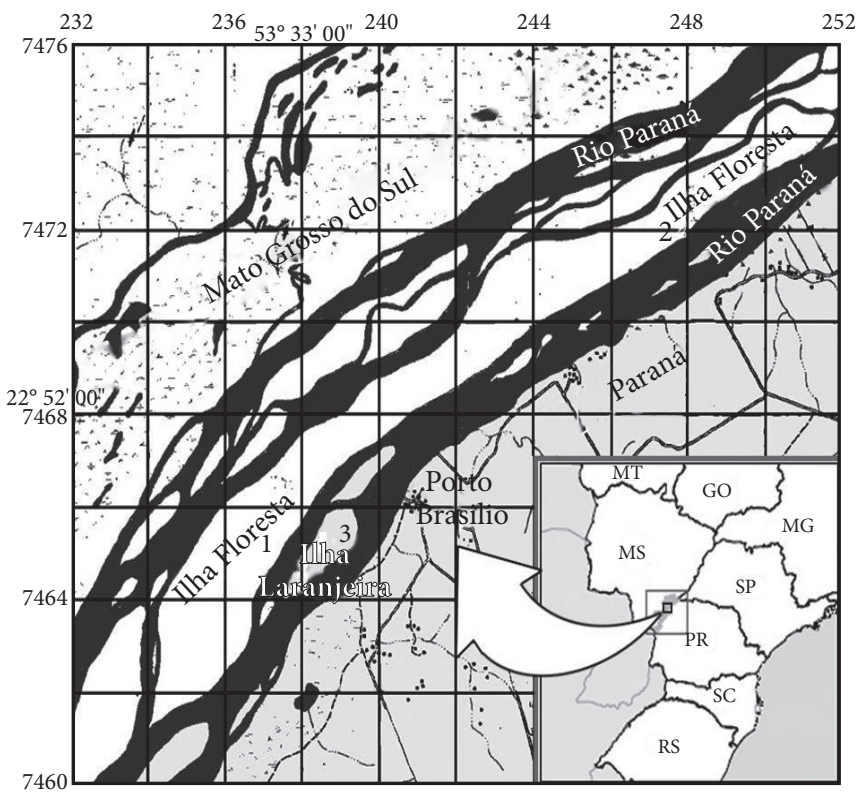

Figure 1. Occurrence of sampling area in Parana River Islands. Numbers 1, 2 and 3 indicate the honey harvesting sites in Floresta and Laranjeira Islands.
Moisture in honey was determined using a specific manual refractometer in natural light and room temperature, with Brix measurement range between $58-90 \%$ specific for honey, according to Atago Co. (1988).

The electrical conductivity $\left(\mu \mathrm{S} . \mathrm{cm}^{-1}\right)$ was obtained using a conductivimeter (GEHAKA) in a solution of $20 \%$ at $20{ }^{\circ} \mathrm{C}$ (RENDÓN, 1996).

The $\mathrm{pH}$ and acidity were measured by the Moraes and Teixeira's method (1998) adopted by the Laboratory of the Centro de Apicultura Tropical at the Instituto de Zootecnia - SP, with the help of pHmeter (HANDYLAB OX10), analytical scale (GEHAKA AG) and magnetic stirrer (EVLAB 017-1).

Formal index was determined by the Moraes' method (1994) using a pHmeter (HANDYLAB OX10), an analytical scale (GEHAKA AG) and a magnetic stirrer (EVLAB, 017-1).

Viscosity was measured using the $100 \mathrm{~S}$ digital (LANE; HENDERSON, 2004) viscosimeter (BROOKFIELD) with the help of a thermostatic bath (Tecnal TE-2000) and stopwatch (MARCHINI; SODRÉ; MORETI, 2004a).

Ash content was measured by calcination in a muffle oven (GEHAKA) at $550{ }^{\circ} \mathrm{C}$ to constant weight (SILVA; QUEIROZ, 2002).

Hydroxymethylfurfural (HMF) was determined according to the AOAC method (ASSOCIATION..., 1990) in a spectrophotometer (METROLAB M1700), which is based on readings of UV absorbance in different wave lengths of 284 and 336 nm (MARCHINI; SODRÉ; MORETI, 2004a).

Total reducing sugars (TRS), reducing sugars (RS) and apparent sucrose (\%) were measured in an oxireduction by titration (Redutec) and Mohr's burette (50 mL), as described by Marchini, Sodré and Moreti (2004a).

Protein was determined following the Silva and Queiroz's method (2002) in a Micro Kjedahl Nitrogen Distiller (TECNAL).

Diastase activity (Goethe scale) was determined by AOAC method (ASSOCIATION..., 1990) in spectrophotometer (METROLAB M1700) at a wavelength of $660 \mathrm{~nm}$.

Color was assessed with a spectrophotometer (METROLAB M1700) at a wavelength of $560 \mathrm{~nm}$ in a $1 \mathrm{~cm}$ cell, using pure glycerin as a white. Subsequently, the value found was transformed in color $(\mathrm{mm})$ by the Pfund scale (VIDAL; FREGOSI, 1984).

The data were statistically analyzed using the Statistical Analysis System Software (2006), using the proc univariate and proc freq for descriptive analysis.

\section{Results and discussion}

The honey produced in Parana River islands were amber, white amber (92\%) and extra white amber. The observed results are in accordance with the Brazilian legislation, which can range from whitish to dark brown (BRASIL, 2000). Honey color is a determining factor in the worldwide commerce, as white honey is preferred by consumers when compared to dark honey (CRANE, 1983). 
These results are similar to those observed by Moreti, Sodré and Marchini(2006) who, when assessing the honey color from six Brazilian states, found a predominance of white amber color. Other authors, such Almeida-Anacleto and Marchini (2004), Mendonça et al. (2008), when studying the honey color from Sao Paulo savannah; Vieira, Marchini and Dalastra (2005) when assessing the honey color in the savannah area of Cassilândia - state of Mato Grosso do Sul and Marchini, Sodré and Moreti (2004b), with samples from state of Tocantins, found predominance of light colors, similar to that observed in this research.

The moisture ranged from 17.37 to $21.70 \%$ for the 24 honey samples analyzed, averaging $18.85 \pm 0.18$, which is within the allowed by the normative instruction, which is $20 \%$ (BRASIL, 2000). However, one of the samples had an excess $(21.70 \%)$. Water is the second component in honey, usually ranging from 15 to $21 \%$, depending on the climate, floral origin and harvest before full dewatering. Typically, the mature honey has less than $18.5 \%$ moisture (MARCHINI; SODRÉ; MORETI, 2004a). In this work, the sample, which exceeds the standards required by the legislation, was early collected by the beekeeper, before its complete maturation, so that the high moisture could not be related to climatic factors nor determined by the honey floral origin.

These results are similar to those found by Almeida-Anacleto and Marchini (2004) who evaluated 34 samples in the Sao Paulo savannah and found a moisture mean of $18.0 \%$; Vieira, Marchini and Dalastra (2005), who evaluated honey samples in the savannah area in Cassilândia - state of Mato Grosso do Sul), found 19.6\%; and Mendonça et al. (2008), when analyzing honey samples produced in the savannah areas in Itirapina - state of São Paulo, observed a mean of $17.21 \%$. Vilhena and Almeida-Muradian (1999) evaluating honey samples from state of Sao Paulo, Cano et al. (2001) evaluating Brazilian honey samples from Eucaliptus and Citrus, and Moreti et al. (2009) evaluating honey samples from state of Ceará reported values from 15.0 to $19.5 \%$. These results are similar to our research.

The $\mathrm{pH}$ ranged from 3.33 to 4.04 , averaging $3.58 \pm 0.18$. This value is similar to that obtained by Almeida-Anacleto and Marchini (2004) in honey samples from Sao Paulo savannah ( $\mathrm{pH}$ mean $3.89 \pm 0.11$ ). Tello Durán et al. (1996) analyzing Brazilian honey samples, reported a range of 3.0 to 5.7 in $\mathrm{pH}$, and the higher value was found in the South region (4.3) and the lowest Northeast region (3.4). Azeredo, Azeredo and Damasceno (1999) reported $\mathrm{pH} 3.65$ in honey samples from São Fidélis (Rio de Janeiro).

Acidity is a major component of honey, since it contributes to its stability, against the development of microorganisms (MARCHINI; SODRÉ; MORETI, 2004a). The acidity of the samples ranged from 28.29 to 56.75 , with a mean $41.77 \pm 7.77$ meq. $\mathrm{kg}^{-1}$.

Three samples had acidity values above $50 \mathrm{meq} \cdot \mathrm{kg}^{-1}$, the maximum allowed by the Brazilian legislation. This mean is close to those obtained by Sodré, Marchini and Carvalho (2002), Marchini, Sodré and Moreti (2004b) and Vieira, Marchini and
Dalastra (2005). However, some authors found mean values lower than those found in this work, such as Arruda et al. (2004), who observed a variation from 6.00 to 13.00 meq. $\mathrm{kg}^{-1}$ with a mean of 8.81 meq. $\mathrm{kg}^{-1}$, Almeida-Anacleto and Marchini (2004), who observed a variation from 6.00 to 46.00 meq. $\mathrm{kg}^{-1}$ in 34 honey samples from state of São Paulo, and Marchini, Sodré and Moreti (2004a) observed 26.2 meq. $\mathrm{kg}^{-1}$ in nine honey samples from state of Paraná.

The formal index ranged from 10.52 to $17.34 \mathrm{~mL} . \mathrm{kg}^{-1}$ with an average of $13.42 \pm 1.94 \mathrm{~mL} \cdot \mathrm{kg}^{-1}$, a similar value to obtained by Komatsu, Marchini and Moreti (2002) in São Paulo (13.9 mL.kg-1 of sugar cane honey) and by Vieira, Marchini and Dalastra (2005), $9.85 \pm 2.93 \mathrm{~mL} \cdot \mathrm{kg}^{-1}$. Brazilian law does not set limits for this parameter (BRASIL, 2000).

The total reducing sugars ranged from 67.13 to 72.04 , with a mean of $68.99 \pm 1.48 \%$. There is nolimit for total reducing sugars in the current legislation, but these results are similar to those observed by several authors who studied honey samples from different Brazilian regions, such as Vilhena and Almeida-Muradian (1999), Komatsu, Marchini and Moreti (2002), Sodré, Marchini and Carvalho (2002), Arruda et al. (2004), Marchini, Sodré and Moreti (2004b) and Vieira, Marchini and Dalastra (2005).

The reducing sugars ranged from 68.49 to $74.60 \%$ and a mean of $71.31 \pm 1.61 \%$. The Brazilian legislation set up a minimum of $65 \%$ for this parameter. The value found is similar to reported by Almeida-Anacleto and Marchini (2004), who evaluated the honey samples of São Paulo savannah, and also by Marchini, Sodré and Moreti (2004a), who evaluated several samples from Paraná. All samples were evaluated and are in accordance with the legislation. The sucrose percentage ranged from 0.80 to $2.91 \%$ with a mean of $2.20 \pm 0.84 \%$. A maximum of $6 \%$ is set up by the Brazilian authorities, and all samples were within the required parameters for apparent sucrose. Marchini, Sodré and Moreti (2004a) found a mean of $4.2 \%$ in honey samples collected in state of Paraná, which is a value closer to that observed in this work, as well as by other authors as Marchini, Sodré and Moreti (2004b) and Vieira, Marchini and Dalastra (2005).

The protein percentage ranged from 0.37 to $0.63 \%$ with a mean of $0.50 \pm 0.07 \%$. This value is higher than observed in different Brazilian states that had protein levels as follows: $0.25 \%$ in Rondônia, $0.29 \%$ in Bahia, $0.34 \%$ in Tocantins, $0.19 \%$ in Piauí, $0.27 \%$ in Ceará, $0.29 \%$ in Mato Grosso do Sul, 0.20 in Mato Grosso, 0.25 in Rio Grande do Sul, 0.37\% in Minas Gerais, $0.28 \%$ in Santa Catarina and $0.30 \%$ in Paraná (MARCHINI ; SODRÉ; MORETI, 2004a). Marchini, Sodré and Moreti (2004b) and Vieira, Marchini and Dalastra (2005) also found values similar to those observed in this research.

Ash values ranged from 0.07 to $0.40 \%$ with a mean of $0.17 \pm 0.08 \%$, which are in accordance with Brazilian law that set up a maximum of $0.6 \%$. These values are similar to those obtained by Marchini, Sodré and Moreti (2004b), who observed an average of $0.18 \%$, very close to those found by Sodré, Marchini and Carvalho (2002), Arruda et al. (2004), and with Silva, Queiróz and Figueirêdo (2004) who found range 
from 0.06 to $0.4 \%$; Evangelista-Rodrigues et al. (2005), from 0.17 to $0.20 \%$; Arruda et al. (2004) average from 0.19\%; Araújo, Silva and Sousa (2006), from 0.06 to $0.15 \%$; and Moreti et al. (2009), from 0.01 to $0.67 \%$.

The electrical conductivity value ranged from 411.66 to $1273.33 \mu \mathrm{S}$ with a mean of $581.06 \pm 0.08 \mu \mathrm{S}$. This parameter is used as an additional method to determine the honey botanical origin (AGANIN, 1971). It is also being used as criteria for the commercialization of honey to Germany: the higher the conductivity, the better is the price paid for the honey. This analysis is correlated with ash content, $\mathrm{pH}$, acidity, minerals, and protein and other substances present in honey (BOGDANOV, 1999). The current Brazilian regulation does not set minimum or maximum limits for these parameters. However, the mean value obtained is within the means $(566.70 \mu \mathrm{S})$ observed by other authors, such as Marchini, Sodré and Moreti (2004b) who analyzed samples from state of Tocantins.

The honey viscosity from the Paraná River islands ranged from 260.0 to $1986.7 \mathrm{mPa}$.s, with mean $1037.4 \pm 443.2 \mathrm{mPa} . \mathrm{s}$ at $25^{\circ} \mathrm{C}$. Brazilian legislation (BRASIL, 2000) and international standards (BOGDANOV, 1999) do not set values for this parameter. Marchini et al. (2004a) recorded mean values of 1499.1 mPa.s in Bahia, 1096.0 mPa.s in Tocantins, $1720.8 \mathrm{mPa} . \mathrm{s}$ in Piaui , $2501.6 \mathrm{mPa}$.s in Ceará, $1202.9 \mathrm{mPa}$.s in Mato Grosso do Sul, $2773.7 \mathrm{mPa}$.s in Mato Grosso, $2472.7 \mathrm{mPa}$.s in Rio Grande do Sul, $1944.1 \mathrm{mPa} . \mathrm{s}$, in Minas Gerais, $1322.0 \mathrm{mPa} . \mathrm{s}$ in Santa Catarina and $1943.3 \mathrm{mPa}$.s in Paraná. Thus, the mean obtained is similar to that observed in most Brazilian states. These results are very close to those observed by Sodré, Marchini and Carvalho (2002) with mean $1607.0 \mathrm{mPa}$.s and Marchini, Sodré and Moreti (2002) with mean $1362.7 \mathrm{mPa}$.s.

The hydroxymethylfurfural (HMF) ranged from 1.0 to $72.4 \mathrm{mg} \cdot \mathrm{kg}^{-1}$, with mean $27.0 \mathrm{mg} \cdot \mathrm{kg}^{-1}$. Two samples were not in accordance with the norms established by the current legislation that is $60.0 \mathrm{mg} \cdot \mathrm{kg}^{-1}$. This is probably due to overheating, a contributing factor for HMF formation. The heating may have been caused by mishandling during honey harvesting in the islands, with the honeycombs exposed to the sun. This type of problem was also reported by Marchini, Sodré and Moreti (2004b).

Despite the HMF in excess in two samples, the remaining $91.7 \%$ is in accordance with the legislation. This result is similar to observed by Marchini, Sodré and Moreti (2004b), with honey from state of Tocantins, mean of $19.7 \mathrm{mg} \cdot \mathrm{kg}^{1}$, Dayrell and Vital (1991), who analyzed Brazilian honey and found values ranging from 1.1 to $248.2 \mathrm{mg} \cdot \mathrm{kg}^{-1}$, and also by Vieira, Marchini and Dalastra (2005) who found a mean of $2.7 \pm 2.4 \mathrm{mg} \cdot \mathrm{kg}^{-1}$. The HMF value reported by Marchini, Sodré and Moreti (2004a) for state of Paraná was $8.9 \mathrm{mg} \cdot \mathrm{kg}^{-1}$.

The last parameter assessed was the diastase activity (Goethe Scale) with a minimum value of 7.6, a maximum of 89.6 and mean $31.7 \pm 21.9$ in Goethe Scale. These results are higher than found in state of Paraná with mean 22.6 in the Goethe scale by Marchini, Sodré and Moreti (2004a). However, it is similar to observed by Marchini, Sodré and Moreti (2004b) with samples from state of Tocantins. Costa, Albuquerque and Turgo (1999) and Sodré, Marchini and Carvalho (2002) observed that one sample $(4.17 \%)$ below the minimum set by the legislation, which requires a minimum of 8 of diastase activity on the Goethe scale. However, most samples had diastase activity within the required standard.

\section{Conclusions}

It was observed of the organic honey samples produced in Paraná River islands, $87 \%$ are of excellent quality, and its physicochemical characteristics are within the Brazilian legislation, with a great perspective in the national and international market.

\section{Acknowledgements}

The National Council for Scientific and Technological Development (CNPq), process number 151242/2004-6, and Coordination of Improvement Staff (CAPES) for their financial support.

\section{References}

AGANIN, A. F. Electrical conductivity of several unifloral honeys. Trudy Saratovskogo Zootekhnicheskogo Inatituta, v. 21, p. 137-144, 1971.

ALMEIDA-ANACLETO, D.; MARCHINI, L. C. Composição físicoquímica de amostras de méis de Apis mellifera L. provenientes do Cerrado Paulista. Boletim de Indústria Animal, v. 61, n. 2, p. 161-172, 2004.

ARAÚJO, D. R.; SILVA, R. H. D.; SOUSA, J. S. Avaliação da qualidade físico-química do mel comercializado na cidade de Crato, CE. Revista de Biologia e Ciência da Terra, v. 6, n. 1, p. 51-55, 2006.

ARRUDA, C. M. F. et al. Características físico-químicas de amostras de méis de Apis mellifera L., 1758 (Hymenoptera, Apidae) da região da Chapada do Araripe, Município de Santana do Cariri, Estado do Ceará. Boletim de Indústria Animal, v. 61, n. 2, p. 141-150, 2004.

ASSOCIATION OF OFFICIAL ANALYTICAL COUNCIL - AOAC. Official methods of analysis. 15th ed. Washington: AOAC, 1990.

ATAGO CO. Refratômetro para mel. CAB Abstracts, v. 31, n. 362, p. 9-44, 1988.

AZEREDO, M. A. A.; AZEREDO, L. C.; DAMASCENO, J. G. J. Características físico-químicas dos méis do município de São / Fidélis-RJ. Ciência e Tecnologia de Alimentos, v. 19, n. 1, p. 3-7, 1999.

BUAININ, A. M.; BATALHA, M. O. Cadeias produtivas de flores e mel. Brasília: MAPA/SPA, 2007.

BOGDANOV, S. Honey quality and international regulatory standards: review by the international honey commission. Bee World, v. 80, n. 2, p. 61-69, 1999.

BRASIL. Ministério da Agricultura. Instrução Normativa n 11 , de 20 de outubro de 2000. Regulamento técnico de identidade e qualidade do mel. Diário Oficial da República Federativa do Brasil, Brasília, DF, 20 out. 1997. Seção 1, p. 16-17.

CANO, C. B. et al. Comparison of methods for determining moisture content of citrus and eucalyptus Brazilian honeys by refractometry. Journal of Food Composition Analysis, v. 14, p. 101-109, 2001. http://dx.doi.org/10.1006/jfca.2000.0951

Costa, L. S. M.; Albuquerque, M. L. S.; TURGO, L. C. Determination of non-volatile compounds of different botanical 
origin Brazilian honeys. Food Chemistry, v. 65, p. 347-352, 1999. http://dx.doi.org/10.1016/S0308-8146(98)00230-1

CRANE, E. O livro do mel. São Paulo: NOBEL, 1983.

DAYRELL, I. O.; VITAL, N. C. Comparação entre dois métodos oficiais para determinação de hidroximetilfurfural (HMF) em mel brasileiro. Ciência e Tecnologia de Alimentos, v. 11, n. 1, p. 137-141, 1991.

EVANGELISTA-RODRIGUES, A. et al. Análise físico-química dos méis de abelhas Apis mellifera e Melipona scutellaris produzidos em regiões distintas no Estado da Paraíba. Ciência Rural, v. 35, n. 5, p. 1166-1171, 2005. http://dx.doi.org/10.1590/S010384782005000500028

INSTITUTO AGRONÔMICO DO PARANÁ - IAPAR. Cartas climáticas do Estado do Paraná. Londrina: IAPAR, 1994.

KOMATSU, S. S.; MARCHINI, L. C.; MORETI, A. C. C. C. Análises físico-químicas de amostras de méis de flores silvestres, de eucalipto e de laranjeira, produzidos por Apis mellifera L., 1758 (Hymenoptera, Apidae) no Estado de São Paulo. 2. Conteúdo de açúcares e de proteína. Ciência e Tecnologia de Alimentos, v. 22, n. 2, p. 143-146, 2002.

LANE, J. L.; HENDERSON, K. O. Viscosity measurement: So easy, yet so difficult. ASTM, 2004. Disponível em: <http://www.astm.org/ SNEWS/JUNE_2004/lanhen_jun04.html>. Acesso em: abr. 2010.

MAAK, R. Geografia física do Estado do Paraná. Curitiba: CODEPAR, 1968.

MARCHINI, L. C.; SODRÉ, G. S.; MORETI, A. C. C. C. Condutividade elétrica, teor de proteína, viscosidade e teor de água de amostras de mel de flores de laranjeira produzido por Apis mellifera L. No Estado de São Paulo. In: SIMPÓSIO INTERNACIONAL DE INICIAÇÃO CIENTÍFICA DA UNIVERSIDADE DE SÃO PAULO, 10. , 2002, Piracicaba. Anais... Piracicaba: Universidade de São Paulo, 2002.

MARCHINI, L. C.; SODRÉ, G. S.; MORETI, A. C. C. C. Mel brasileiro: composição e normas. Ribeirão Preto: São Francisco, 2004a.

MARCHINI, L. C.; SODRÉ, G. S.; MORETI, A. C. C. C. Composição físico-química de amostras de méis de Apis mellifera L. do estado do Tocantins, Brasil. Boletim de Indústria Animal, v. 61, n. 2, p. 101-114, 2004b.

MENDONÇA, K. et al. Caracterização físico-química de amostras de méis produzidas por Apis mellifera L. em fragmento de cerrado no município de Itirapina, São Paulo. Ciência Rural, v. 38, n. 6, p. $1748-1753,2008$.

MORAES, R. M. Analise de mel. São Paulo: Centro de Apicultura Tropical, IZ/SAA, 1994.

MORAES, R. M.; TEIXEIRA, E. W. Análise de mel. Pindamonhangaba: SN, 1998.
MORETI, A. C. C. C.; SODRÉ, G. S.; MARCHINI, L. C. Cor de amostras de mel de Apis mellifera L. de diferentes estados brasileiros. Boletim de Indústria Animal, v. 63, n. 3, p. 159-164, 2006.

MORETI, A. C. C. C. et al. Características físico-químicas de amostras de méis de Apis mellifera l. do estado do Ceará, Brasil. Ciência e Agrotecnologia, v. 33, n. 1, p. 191-199, 2009. http://dx.doi. org/10.1590/S1413-70542009000100027

PEREIRA, J. G. Mel de abelhas - análises de amostras comercializadas no município de Campo Grande - MS. Revista Higiene Alimentar, v. 2, n. 4, p. 23-26, 1983.

RENDÓN, S. R. Estudio de la composicion fisicoquimica de las mieles extremeñas y extranjeras. In: CONGRESSO IBERO LATINOAMERICANO DE APICULTURA, 5., 1996, Uruguai. Anais... Uruguai, 1996. p. 174-83.

STATISTICAL ANALISYS SYSTEM INSTITUTE - SAS. User's guide: statistics. Version 8. 13th ed. Cary: SAS INSTITUTE, 2006.

SILVA, D. J.; QUEIROZ, A. C. Análise de alimentos: métodos químicos e biológicos. Viçosa: UFV, 2002.

SILVA, C. L.; QUEIROZ, A. J. M.; FIGUEIRÊDO, R. M. F. Caracterização físico-química de méis produzidos no Estado do Piauí para diferentes floradas. Revista Brasileira de Engenharia Agrícola e Ambiental, v. 8, n. 2-3, p. 260-265, 2004. http://dx.doi. org/10.1590/S1415-43662004000200015

SODRÉ, G. S.; MARCHINI, L. C.; CARVALHO, C. A. L. Características físico-químicas de amostras de méis de abelha Apis mellifera L., 1758 (Hymenoptera; Apidae) da região litoral norte do Estado da Bahia. Revista Agrícola, v. 77, n. 2, p. 243-256, 2002.

TELLO DURÁN, J. E. et al. Méis brasileiros: resultados de análises físico-químicas e palinológicas. In: CONGRESSO BRASILEIRO DE APICULTURA, 11., 1996, Teresina. Anais... Teresina: FBA, 1996. p. 403-429.

VIDAL, R.; FREGOSI, E. V. Mel: características, análises físicoquímicas, adulteração e transformação. Barretos: Instituto Tecnológico Científico "Roberto Rios”, 1984.

VIEIRA, G. H. C.; MARCHINI, L. C.; DALASTRA, C. Caracterização físico-química de méis produzidos por Apis mellifera L. (Hymenoptera: Apidae) em área de cerrado no município de Cassilândia, MS. Boletim de Indústria Animal, v. 62, n. 3, p. 203-214, 2005.

VILHENA, F; ALMEIDA-MURADIAN, L. B. Manual de análises físico-químicas de mel. São Paulo: APACAME, 1999.

WHITE JUNIOR, J. W. Honey. Advances in Food Research, v. 22, p. $287-374,1978$. 